\title{
The Relationship Between Lymphocyte Subsets and the Prognosis and Genomic Features of Lung Cancer: A Retrospective Study
}

\section{Shuiping Dai}

Sichuan University West China Hospital

\section{Pengwei Ren}

Sichuan University West China Hospital

Jing Ren

Sichuan University West China Hospital

\section{Lan Yang}

Sichuan University West China Hospital

Weimin Li ( $\nabla$ weimi003@scu.edu.cn )

Sichuan University West China Hospital

Research article

Keywords: CD3+ T lymphocytes, CD8+ T lymphocytes, EGFR mutation, lung cancer, prognosis

Posted Date: July 10th, 2020

DOl: https://doi.org/10.21203/rs.3.rs-40789/v1

License: (c) (1) This work is licensed under a Creative Commons Attribution 4.0 International License. Read Full License 


\section{Abstract \\ Background}

It has been shown that the prognosis of malignant tumors was closely related to the composition and function of immune system, which was associated with genomic features. However, the prognostic value of peripheral T lymphocyte subsets and its relationship with genomic features in lung cancer has not been analyzed extensively. Therefore, this study was intended to evaluate the relationship between lymphocyte subsets and the prognosis and genomic features of lung cancer.

\section{Methods}

598 lung cancer patients with complete data were included in this study between 2011 and 2018. KaplanMeier method and Pearson analyses were conducted to study the prognostic value of CD3+, CD4+, CD $8+$ $T$ lymphocytes and the rate of CD4/CD8.

\section{Results}

Patients with EGFR mutation has lower percentage of CD8 + lymphocytes than patients with EGFR wildtype (24.71 versus 26.62 , respectively, $P=0.041$ ). Patients with high CD3 + had better OS than those with low (27 versus 14 months, $P=0.002$ ). OS of higher CD $4+$ and CD4/CD8 rate had longer OS than of lower (27 versus 12 months, $P=0.002 ; 25$ versus 9 months, $P=0.008$, respectively). Patients with high CD $8+$ had poor PFS than low group ( 6 versus 11 months, $P=0.009$ ). There was a negative correlation between $C D 3+$ and $C D 4+$ cells and OS in smoking stage 2 female lung cancer patients $(P C C=0.626, P<0.05$; $P C C=0.534, P<0.05$, respectively). In stage 1 male lung cancer patients, CD8 $+T$ cell is negatively correlated with OS and PFS (PCC $=0.295, \mathrm{P}<0.05 ; \mathrm{PCC}=0.280, \mathrm{P}<0.05$, respectively)

\section{Conclusions}

Lung cancer patients with EGFR mutation had lower percentage of CD8 + lymphocytes. Lymphocyte subsets might be potential prognostic biomarkers of lung cancer, but they are affected by gender and tumor stage.

\section{Background}

Lung cancer has become the most common malignant tumor with the highest mortality rate in the world[1]. It accounts for about a quarter of all cancer deaths[2]. Although the treatment of lung cancer, such as surgery, radiotherapy, chemotherapy and targeted therapy, has made great progress in recent years, the prognosis of lung cancer is still poor because most patients have been diagnosed in the locally 
advanced stage or in the stage of extensive metastasis[3]. The five-year survival rate for patients with localized lung cancer is about $55 \%$, while for patients with distant metastasis is only $4 \%[4,5]$.

A series of studies have shown that the occurrence, development and prognosis of malignant tumors are closely related to the composition and function of immune system[6, 7]. The systemic effects of tumor can make distant tissues and organs change in favor of metastasis and promote the progress of tumor[8-13]. The metastasis of lung cancer is related to the increase of circulating tumor cells [14], which can be influenced by the change of CD3+, CD4 + cells in peripheral blood[15]. A study about laryngeal squamous cell cancer indicates lower CD4+/CD $8+$ ratios are related to recurrent disease and a higher level of CD3 + and CD4 + is associated with nodal metastasis[16]. The increased risk of lung cancer is associated with low CD4 cell count and low CD4/CD8 ratio[17]. However, the prognostic value of peripheral $\mathrm{T}$ lymphocytes subsets in lung cancer has not been proved by studies with large data.

It has been reported that the genomic features of lung cancer were associated with inflammatory tumorinfiltrating lymphocytes[18]. For example, the infiltrating B lymphocyte abundance was higher in the EGFR-mutated patients[19]. However, the relationship between genomic features and circulating lymphocyte subsets was not clear. Hence, our study was aimed to evaluate the relationship between lymphocyte subsets and the prognosis and genomic features of lung cancer.

\section{Methods}

\section{Patients and data collection}

We retrospectively reviewed the medical records of patients who diagnosed with lung cancer at West China Hospital, Sichuan University, from January 2011 to January 2018. Inclusion criteria were: lung cancer patients, age $>18$ years, with enough clinical and blood test data, no previous treatment for lung cancer before diagnosis. Criteria for exclusion from this study were: individuals with other malignancies or combined with immune system disease, with an infection history or using drugs which could affect their immune system within one month before diagnosis.

Clinical and pathological data of included patients were collected through the medical record management system of West China Hospital. The basic information collected were: age at diagnosis, gender, smoking history, and histology. TNM stage of all patients were restaged according to the 8th International Classification System for Lung Cancer[20]. Peripheral indicators were obtained $<1$ week prior to the first treatment, including the proportion of $C D 3+, C D 4+, C D 8+T$ lymphocyte subpopulations and the ratio of $\mathrm{CD} 4 / \mathrm{CD} 8$.

EGFR mutation, ALK and ROS-1 rearrangements testing

Tumor specimens used for EGFR mutation, ALK and ROS-1 rearrangements detection were obtained from surgery, bronchoscopy, computed tomography (CT)-guided biopsy, and pleural effusion. EGFR mutation detection was carried out using Amplification Refractory Mutation System technology as the ADx EGFR 
Mutations Detection Kit (Amoy Diagnostics, China) had been approved for clinical application by the State Food and Drug Administration in China. ALK and ROS-1 gene testing was conducted on biopsy samples using immunostaining or the fluorescence in situ hybridization (FISH) method.

\section{Statistical analysis}

The survival data included overall survival (OS) and progression-free survival (PFS). OS was defined as the time from the start of treatment to death from any cause. PFS was the time from start of treatment to radiographic or clinical progression or death from any cause. Patients who had not progressed or died at the last time of follow-up were censored at the date of the last contact.

X-tile software (Yale University, New Haven, CT, USA) was used to determine the optimal cut-off values of CD3+, CD4+, CD8+, CD4+/CD8+, NLR, and PLR for predicting lung cancer prognosis[21]. Kaplan-Meier curves were used for the analysis of OS and PFS. The difference between groups were compared by the log-rank test. Canonical Correlation Analysis (Canoco 5.0) and Pearson analysis were used to evaluate the correlation between CD3+, CD4+, CD8+, CD4+/CD8+, NLR, PLR, and other characteristics of lung cancer and PFS, OS. The comparation of lymphocyte subsets between different genomic features was performed by t-test. Two-tailed $P$ values of $<0.05$ were considered to define statistical significance. All statistical analyses were carried out using SPSS 20.0 (IBM Corp., Armonk, NY, USA).

\section{Results}

\section{Patients characteristics}

597 lung cancer patients with enough clinical and peripheral blood data were included in this study. The baseline characteristics of these patients were shown in Table 1. Median age of this patients was 61 years old. More than half of patients were male (58.96\%) and smokers (53.77\%). 397 (66.5\%) individuals were diagnosed with adenocarcinoma. The majority of patients were diagnosed at late tumor

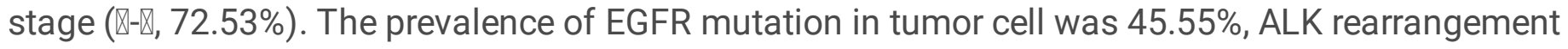
$8.11 \%$, ROS-1 rearrangement $2.56 \%$, PD-L1 expression positive $59.01 \%$. 
Table 1

The clinical-pathological characteristics of patients (N (\%))

\begin{tabular}{|c|c|c|}
\hline \multirow[t]{2}{*}{ Age, years } & median & 61 \\
\hline & range & $20-87$ \\
\hline \multirow[t]{2}{*}{ Gender } & Male & $352(58.96)$ \\
\hline & Female & $245(41.04)$ \\
\hline \multirow[t]{2}{*}{ Smoking } & No & $276(46.23)$ \\
\hline & Yes & 321 (53.77) \\
\hline \multirow[t]{3}{*}{ Histology } & Adenocarcinoma & $397(66.50)$ \\
\hline & Squamous carcinoma & $100(16.75)$ \\
\hline & Others & $100(16.75)$ \\
\hline \multirow[t]{4}{*}{ Stage } & ૧ & $103(17.25)$ \\
\hline & प & $61(10.22)$ \\
\hline & [ & 167 (27.97) \\
\hline & ૧ & $266(44.56)$ \\
\hline \multirow[t]{2}{*}{ CD3 (\%) } & mean & 66.69 \\
\hline & Standard deviation & 10.89 \\
\hline \multirow[t]{2}{*}{ CD4 (\%) } & mean & 36.98 \\
\hline & Standard deviation & 9.44 \\
\hline \multirow[t]{2}{*}{ CD8 (\%) } & mean & 25.27 \\
\hline & Standard deviation & 9.19 \\
\hline \multirow[t]{2}{*}{ CD4/CD8 } & mean & 1.76 \\
\hline & Standard deviation & 1.53 \\
\hline \multirow[t]{2}{*}{ EGFR mutation } & positive & $169(45.55 \%)$ \\
\hline & negative & $202(54.45 \%)$ \\
\hline \multirow[t]{2}{*}{ ALK rearrangement } & positive & $36(8.11 \%)$ \\
\hline & negative & 408 (91.89\%) \\
\hline \multirow[t]{2}{*}{ ROS-1 rearrangement } & positive & $9(2.56 \%)$ \\
\hline & negative & $343(97.44 \%)$ \\
\hline PD-L1 expression & positive & 95 (59.01\%) \\
\hline
\end{tabular}




\begin{tabular}{|lll|}
\hline Age, years & median & 61 \\
\hline & negative & $66(40.99 \%)$ \\
\hline
\end{tabular}

The percentage of T-lymphocyte subsets in lung cancer patients with different genomic aberration and PD-L1 expression was shown in Table 2. Patients with EGFR mutation has lower percentage of CD8 + lymphocytes than patients with EGFR wild-type ( $24.71 \pm 8.69$ and $26.62 \pm 9.23$, respectively, $P=0.041)$. There was no significant difference in the proportion of T-lymphocyte subsets between PD-L1 positive and negative patients.

Table 2

Circulating T-lymphocyte subsets of different patients with lung cancer (mean ( \pm standard deviation))

\begin{tabular}{|c|c|c|c|c|c|c|c|c|}
\hline & CD3 (\%) & $\begin{array}{l}P \\
\text { value }\end{array}$ & CD4 (\%) & $\begin{array}{l}P \\
\text { value }\end{array}$ & CD8 (\%) & $\begin{array}{l}P \\
\text { value }\end{array}$ & CD4/CD8 & $\begin{array}{l}P \\
\text { value }\end{array}$ \\
\hline $\begin{array}{l}\text { EGFR } \\
\text { mutation }\end{array}$ & & 0.368 & & 0.389 & & 0.041 & & 0.938 \\
\hline positive & $\begin{array}{l}67.26( \pm \\
10.90)\end{array}$ & & $\begin{array}{l}37.72 \\
( \pm 8.77)\end{array}$ & & $\begin{array}{l}24.71( \pm \\
8.69)\end{array}$ & & $\begin{array}{l}1.80( \pm \\
0.98)\end{array}$ & \\
\hline negative & $\begin{array}{l}68.25( \pm \\
10.28)\end{array}$ & & $\begin{array}{l}36.92 \\
( \pm 9.11)\end{array}$ & & $\begin{array}{l}26.62( \pm \\
9.23)\end{array}$ & & $\begin{array}{l}1.78( \pm \\
2.59)\end{array}$ & \\
\hline $\begin{array}{l}\text { ALK } \\
\text { rearrangement }\end{array}$ & & 0.774 & & 0.231 & & 0.184 & & 0.289 \\
\hline positive & $\begin{array}{l}67.99( \pm \\
9.18)\end{array}$ & & $\begin{array}{l}35.82 \\
( \pm 8.95)\end{array}$ & & $\begin{array}{l}27.19 \\
8.08)\end{array}( \pm$ & & $\begin{array}{l}1.48( \pm \\
0.74)\end{array}$ & \\
\hline negative & $\begin{array}{l}66.46( \pm \\
10.57)\end{array}$ & & $\begin{array}{l}37.69 \\
( \pm 8.98)\end{array}$ & & $\begin{array}{l}25.18( \pm \\
8.74)\end{array}$ & & $\begin{array}{l}1.82( \pm \\
1.93)\end{array}$ & \\
\hline $\begin{array}{l}\text { ROS-1 } \\
\text { rearrangement }\end{array}$ & & 0.768 & & 0.177 & & 0.334 & & 0.816 \\
\hline positive & $\begin{array}{l}69.02 \\
11.85)\end{array}( \pm$ & & $\begin{array}{l}41.90 \\
( \pm 8.33)\end{array}$ & & $\begin{array}{l}22.64( \pm \\
5.95)\end{array}$ & & $\begin{array}{l}1.96( \pm \\
0.65)\end{array}$ & \\
\hline negative & $\begin{array}{l}67.96( \pm \\
10.58)\end{array}$ & & $\begin{array}{l}37.78 \\
( \pm 9.03)\end{array}$ & & $\begin{array}{l}25.49( \pm \\
8.77)\end{array}$ & & $\begin{array}{l}1.80( \pm \\
2.04)\end{array}$ & \\
\hline $\begin{array}{l}\text { PD-L1 } \\
\text { expression }\end{array}$ & & 0.834 & & 0.308 & & 0.075 & & 0.069 \\
\hline positive & $\begin{array}{l}69.58( \pm \\
9.29)\end{array}$ & & $\begin{array}{l}37.70 \\
( \pm 9.75)\end{array}$ & & $\begin{array}{l}27.50( \pm \\
10.46)\end{array}$ & & $\begin{array}{l}1.58( \pm \\
0.722)\end{array}$ & \\
\hline negative & $\begin{array}{l}69.94( \pm \\
11.72)\end{array}$ & & $\begin{array}{l}39.19 \\
( \pm 8.64)\end{array}$ & & $\begin{array}{l}24.79( \pm \\
8.68)\end{array}$ & & $\begin{array}{l}1.80( \pm \\
0.792)\end{array}$ & \\
\hline
\end{tabular}

Survival outcomes 
The percentage of pretreatment circulating CD3+, CD4+, CD 8 + lymphocytes and CD4/CD8 ratio were $67.8 \%, 37.4 \%, 24.2 \%$, and 1.54 respectively. Median NLR was 3.39 and PLR was 138.94 . The cut-off values of these indicators for predicting prognosis in lung cancer patients were defined by X-tile software. CD3 was $67.25 \%$, CD 4 was $42 \%$, CD 8 was $33.9 \%$, CD $4 / C D 8$ was 1.085 , NLR was 1.9 , and PLR was 213.8 . Patients were stratified into 2 groups (low groups and high groups) by the cut-off value of these indicators, when Kaplan-Meier curves and log-rank test were used for the analysis of OS and PFS.

The median OS of all included lung cancer patients was 23 months ( $95 \%$ confidence interval $(\mathrm{Cl}), 18.56-$ 27.44), and the median PFS was 10 months (95\%,7.76-12.24). The OS rates of patients according to CD3+, CD4+, CD8+, and CD4/CD8 were shown in Fig. 1. The CD3-high group had higher OS than the CD3low group, with a median OS of 27 versus 14 months $(P=0.002)$. Patients with higher CD4 + shown longer OS (CD4-high versus CD4-low, 27 versus 12 months, $P=0.002$ ). The higher rate of CD4/CD8 also had better OS (CD4/CD8-high versus CD4/CD8-low, 25 versus 9 months, $P=0.008$ ). However, OS showed no significant difference between CD8-high and CD8-low group (16 versus 25 months, $P=0.1$ ). Patients with higher $\mathrm{CD} 3+, \mathrm{CD} 4+$, or $\mathrm{CD} 4 / \mathrm{CD} 8$ rate had longer PFS (11 versus 8 months, $P=0.017 ; 11$ versus 5 months, $P=0.003 ; 11$ versus 5 months, $P=0.002$, respectively). Conversely, the CD8-high group had poor PFS than the CD8-low group ( 6 versus 11 months, $P=0.009$ ). The PFS rates of patients according to $\mathrm{CD} 3+, \mathrm{CD} 4+, \mathrm{CD} 8+$, and CD4/CD8 were shown in Fig. 2. The OS and PFS was significant longer in the NLR-low group (OS, 88 versus 19 months, $P<0.001$; PFS, 26 versus 7 months, $P<0.001$, respectively), which was also found in the PLR-low group (OS, 29 versus 11 months, $P<0.001 ;$ PFS, 13 versus 4 months, $P<0.001$, respectively) (Additional file 1 ).

The correlation between lymphocyte subsets and prognosis

Canonical Correlation Analysis was used to analysis the correlation between lymphocyte subsets, clinical characteristics and prognosis of lung cancer. As shown in Fig. 3, gender and stage had potential impacts on PFS and OS. Smoking had an impact on the prognosis of female patients. According to clinical characteristic, the patients were divided into different groups to explore the relationship between lymphocyte and prognosis. In non-smoking stage 2 female lung cancer patients, $C D 8+T$ cell is positively correlated with OS and PFS (Pearson correlation coefficient $(P C C)=0.587, P<0.05 ; \mathrm{PCC}=0.586, P<0.05$, respectively) (Additional file 2). There was a negative correlation between CD $3+$ and $C D 4+$ cells and OS in smoking stage 2 female lung cancer patients $(P C C=0.626, P<0.05 ; P C C=0.534, P<0.05$, respectively) (Additional file 3). In stage 1 male lung cancer patients, $C D 8+T$ cell is negatively correlated with $O S$ and PFS (PCC $=0.295, P<0.05 ; \mathrm{PCC}=0.280, P<0.05$, respectively) (Additional file 4). Indicators related to the prognosis of patients with lung cancer are listed in Fig. 4.

\section{Discussion}

This study indicated that the high level of peripheral CD3+, CD4 + $T$ cell and CD4/CD8 ratio were associated with longer OS in lung cancer patients. However, the high baseline of CD8 $+T$ cells was 
significant predictors of poor PFS. Lung cancer patients with EGFR mutation had lower percentage of CD8 + lymphocytes.

Previous study observed that the risk of lung cancer was associated with low CD 4 cell count and low $\mathrm{CD} 4 / \mathrm{CD} 8$ ratio[17]. Peripheral CD8 $+\mathrm{T}$ cells was higher in lung cancer patients compared to the health, while $\mathrm{CD} 3+$ and $C D 4+T$ cells, and CD4/CD8 ratio was significantly lower[22]. The relationship of lower $\mathrm{CD} 4+/ \mathrm{CD} 8+$ ratios and recurrent disease and higher level of CD3+/CD $4+$ and nodal metastasis was found in laryngeal squamous cell cancer[16].

In our study, the prevalence of EGFR mutation in tumor cell was $45.55 \%$, ALK rearrangement $8.11 \%$, ROS-1 rearrangement $2.56 \%$, which was similar to the results of other studies[23-25]. The expression of PD-L1 in tumor cell was consistent with previous studies[26, 27]. We found patients with EGFR mutation had lower percentage of circulating CD8 $+T$ cells. A precious study found there was no significant difference in the proportion of tumor infiltration $\mathrm{CD} 8+\mathrm{T}$ cell between EGFR mutation and EGFR wild-type patients[28]. Future researches are need to clarify the relationship of $T$ lymphocytes and EGFR mutation in lung cancer.

The survival curve of this study showed that peripheral $C D 4+T$ cells but not $C D 8+T$ cells were associated with OS in lung cancer. A previous research also indicated that tumor infiltrating CD4+T cells, not CD $8+T$ cells, were associated with favorable prognosis in human non-small cell lung cancers[29]. In contrast, an meta-analysis found that CD4 + T cells in tumor compartment had no influence on OS, while $\mathrm{CD} 8+\mathrm{T}$ cells were associated with better prognosis in terms of OS in non-small cell lung cancer patients[30]. They also found that elevated CD3 $+T$ cells was associated with improved OS, which was constant with our results. Another meta-analysis clarified that high level of CD3+, CD4+, and CD $8+T$ cells infiltration showed better OS in lung cancer patients[31]. The distant prognosis value of T cells in different sites was needed to be explored by more researches. Increased CD $8+C D 28+T$ cells independently predicted favorable OS and PFS in lung adenocarcinoma, while high levels of CD8 + CD28$T$ cells predicted unfavorable OS and PFS in lung squamous cell carcinoma[32]. The prognosis value was associated with the subtypes of CD8 $+T$ cells. Therefore, the prognostic value of different subtypes of $\mathrm{CD} 4+/ \mathrm{CD} 8+\mathrm{T}$ cells in lung cancer were needed to be studied by more researches.

\section{Conclusion}

Lung cancer patients with EGFR mutation had lower percentage of CD8 + lymphocytes. High level of peripheral $C D 3+T$ cells predict longer OS in lung cancer patients, while high level of peripheral CD8 $+T$ cells are associated with poor PFS. Lymphocyte subsets might be potential prognostic biomarkers of lung cancer, but they are affected by gender and tumor stage.

\section{Abbreviations}

EGFR 
Epidermal growth factor receptor; OS:Overall survival; PFS:Progression-free survival; ROS-1:Protooncogene receptor tyrosine kinase; ALK:Anaplastic lymphoma kinase; HR:Hazard ratio; Cl:Confidence interval; PCC:Pearson correlation coefficient.

\section{Declarations}

Ethics approval and consent to participate

Our study was approved by the ethics committee of West China hospital (IRB:2018/488) and carried out following the local ethical guidelines.

Consent for publication

Not applicable.

Availability of data and materials

The datasets used and/or analyzed during the current study are available from the corresponding author on reasonable request.

Competing interests

The authors declare that they have no competing interests.

Funding

This study was supported by the National Natural Science Foundation of China (grant number: 91859203).

Authors' contributions

Dai Shuiping, Li Weimin, Ren Pengwei, and Yang Lan made substantial contributions to the design of this study. Dai Shuiping, R Pengwei, and Yang Lan acquired the clinical data. Dai Shuiping and Ren Pengwei drafted this manuscript, which was critically revised by Li Weimin.

Acknowledgements

We thank Wang Chengdi for the screening of the medical records.

\section{References}

1. Bray F, Ferlay J, Soerjomataram I, Siegel RL, Torre LA, Jemal A. Global cancer statistics 2018: GLOBOCAN estimates of incidence and mortality worldwide for 36 cancers in 185 countries. $C A$ Cancer J Clin 2018.

2. Siegel RL, Miller KD. Cancer statistics, 2019. 2019, 69(1):7-34. 
3. Herbst RS, Morgensztern D, Boshoff $C$. The biology and management of non-small cell lung cancer. Nature. 2018;553(7689):446-54.

4. Miller KD, Siegel RL, Lin CC, Mariotto AB, Kramer JL, Rowland JH, Stein KD, Alteri R, Jemal A. Cancer treatment and survivorship statistics, 2016. CA Cancer J Clin. 2016;66(4):271-89.

5. Siegel RL, Miller KD, Jemal A. Cancer Statistics, 2017. CA Cancer J Clin. 2017;67(1):7-30.

6. Thorsson V, Gibbs DL, Brown SD, Wolf D, Bortone DS, Ou Yang TH, Porta-Pardo E, Gao GF, Plaisier CL, Eddy JA, et al. The Immune Landscape of Cancer. Immunity. 2018;48(4):812-30 e814.

7. Schreiber RD, Old LJ, Smyth MJ. Cancer immunoediting: integrating immunity's roles in cancer suppression and promotion. Science. 2011;331(6024):1565-70.

8. Kim S, Takahashi H, Lin WW, Descargues P, Grivennikov S, Kim Y, Luo JL, Karin M. Carcinomaproduced factors activate myeloid cells through TLR2 to stimulate metastasis. Nature. 2009;457(7225):102-6.

9. Erler JT, Bennewith KL, Cox TR, Lang G, Bird D, Koong A, Le QT, Giaccia AJ. Hypoxia-induced lysyl oxidase is a critical mediator of bone marrow cell recruitment to form the premetastatic niche. Cancer Cell. 2009;15(1):35-44.

10. Oppenheimer SB. Cellular basis of cancer metastasis: A review of fundamentals and new advances. Acta Histochem. 2006;108(5):327-34.

11. Hiratsuka S, Watanabe A, Aburatani H, Maru Y. Tumour-mediated upregulation of chemoattractants and recruitment of myeloid cells predetermines lung metastasis. Nat Cell Biol. 2006;8(12):1369-75.

12. Hiratsuka S, Nakamura K, Iwai S, Murakami M, Itoh T, Kijima H, Shipley JM, Senior RM, Shibuya M. MMP9 induction by vascular endothelial growth factor receptor-1 is involved in lung-specific metastasis. Cancer Cell. 2002;2(4):289-300.

13. Sceneay J, Chow MT, Chen A, Halse HM, Wong CS, Andrews DM, Sloan EK, Parker BS, Bowtell DD, Smyth MJ, et al. Primary tumor hypoxia recruits CD11b+/Ly6Cmed/Ly6G + immune suppressor cells and compromises NK cell cytotoxicity in the premetastatic niche. Cancer Res. 2012;72(16):3906-11.

14. O'Flaherty JD, Gray S, Richard D, Fennell D, O'Leary JJ, Blackhall FH, O'Byrne KJ. Circulating tumour cells, their role in metastasis and their clinical utility in lung cancer. Lung Cancer. 2012;76(1):19-25.

15. Ye L, Zhang F. Circulating Tumor Cells Were Associated with the Number of T Lymphocyte Subsets and NK Cells in Peripheral Blood in Advanced Non-Small-Cell Lung Cancer. 2017, 2017:5727815.

16. Marchi F, Missale F, Incandela F, Filauro M, Mazzola F, Mora F, Paderno A, Parrinello G, Piazza C, Peretti G. Prognostic Significance of Peripheral T-Cell Subsets in Laryngeal Squamous Cell Carcinoma. Laryngoscope investigative otolaryngology. 2019;4(5):513-9.

17. Sigel K, Wisnivesky J, Crothers K, Gordon K, Brown ST, Rimland D, Rodriguez-Barradas MC, Gibert C, Goetz MB, Bedimo R, et al. Immunological and infectious risk factors for lung cancer in US veterans with HIV: a longitudinal cohort study. The Lancet HIV. 2017;4(2):e67-73.

18. Zhang XC, Wang J, Shao GG, Wang Q, Qu X, Wang B, Moy C, Fan Y, Albertyn Z, Huang X, et al. Comprehensive genomic and immunological characterization of Chinese non-small cell lung cancer 
patients. Nature communications. 2019;10(1):1772.

19. Wang C, Yin R, Dai J, Gu Y, Cui S, Ma H, Zhang Z, Huang J, Qin N, Jiang T, et al. Whole-genome sequencing reveals genomic signatures associated with the inflammatory microenvironments in Chinese NSCLC patients. Nat Med. 2018;9(1):2054.

20. Goldstraw P, Chansky K, Crowley J, Rami-Porta R, Asamura H, Eberhardt WE, Nicholson AG, Groome P, Mitchell A, Bolejack V, et al. The IASLC Lung Cancer Staging Project: Proposals for Revision of the TNM Stage Groupings in the Forthcoming (Eighth) Edition of the TNM Classification for Lung Cancer. J Thorac Oncol. 2016;11(1):39-51.

21. Camp RL, Dolled-Filhart M, Rimm DL. X-tile: a new bio-informatics tool for biomarker assessment and outcome-based cut-point optimization. Clin Cancer Res. 2004;10(21):7252-9.

22. Woo EY, Yeh H, Chu CS, Schlienger K, Carroll RG, Riley JL, Kaiser LR, June CH. Cutting Edge: Regulatory T Cells from Lung Cancer Patients Directly Inhibit Autologous T Cell Proliferation. J Immunol. 2002;168(9):4272-6.

23. Pao W, Girard N. New driver mutations in non-small-cell lung cancer. Lancet Oncol. 2011;12(2):17580.

24. Korpanty GJ, Graham DM, Vincent MD, Leighl NB. Biomarkers That Currently Affect Clinical Practice in Lung Cancer: EGFR, ALK, MET, ROS-1, and KRAS. Front Oncol. 2014;4:204.

25. Kwak EL, Bang YJ, Camidge DR, Shaw AT, Solomon B, Maki RG, Ou SH, Dezube BJ, Jänne PA, Costa $\mathrm{DB}$, et al. Anaplastic lymphoma kinase inhibition in non-small-cell lung cancer. N Engl J Med. 2010;363(18):1693-703.

26. Yu H, Boyle TA, Zhou C, Rimm DL, Hirsch FR. PD-L1 Expression in Lung Cancer. J Thorac Oncol. 2016;11(7):964-75.

27. Azuma K, Ota K, Kawahara A, Hattori S, Iwama E, Harada T, Matsumoto K, Takayama K, Takamori S, Kage $M$, et al. Association of PD-L1 overexpression with activating EGFR mutations in surgically resected nonsmall-cell lung cancer. Ann Oncol. 2014;25(10):1935-40.

28. Liu SY, Dong ZY, Wu SP, Xie Z, Yan LX, Li YF, Yan HH, Su J, Yang JJ, Zhou Q, et al. Clinical relevance of PD-L1 expression and CD8 + T cells infiltration in patients with EGFR-mutated and ALK-rearranged lung cancer. Lung Cancer. 2018;125:86-92.

29. Wakabayashi O, Yamazaki K, Oizumi S, Hommura F, Kinoshita I, Ogura S, Dosaka-Akita H, Nishimura M. CD4 + T cells in cancer stroma, not CD8 + T cells in cancer cell nests, are associated with favorable prognosis in human non-small cell lung cancers. Cancer Sci. 2003;94(11):1003-9.

30. Soo RA, Chen Z, Yan Teng RS, Tan HL, lacopetta B, Tai BC, Soong R: Prognostic significance of immune cells in non-small cell lung cancer. meta-analysis. Oncotarget 2018, 9(37):24801-24820.

31. Geng Y, Shao Y, He W, Hu W, Xu Y, Chen J, Wu C, Jiang J. Prognostic Role of Tumor-Infiltrating Lymphocytes in Lung Cancer: a Meta-Analysis. Cell Physiol Biochem. 2015;37(4):1560-71.

32. Liu C, Jing W, An N, Li A, Yan W, Zhu H, Yu J. Prognostic significance of peripheral CD $8+$ CD28 + and CD8 + CD28- T cells in advanced non-small cell lung cancer patients treated with chemo(radio)therapy. J Transl Med. 2019;17(1):344. 
Figures
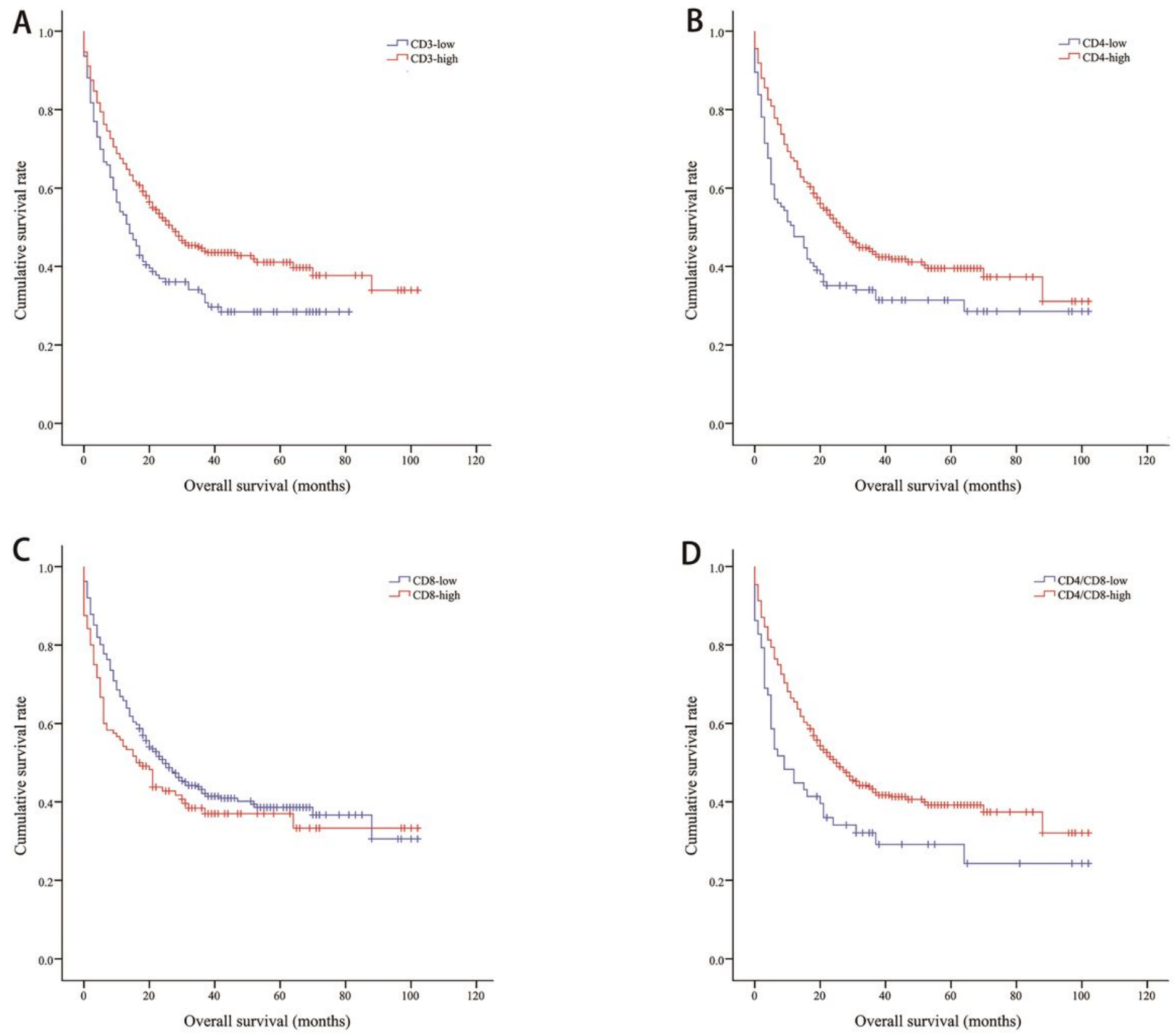

Figure 1

Kaplan-Meier curves showing overall survival by CD3 (A), CD4 (B), CD8 (C), CD4/CD8 (D) 

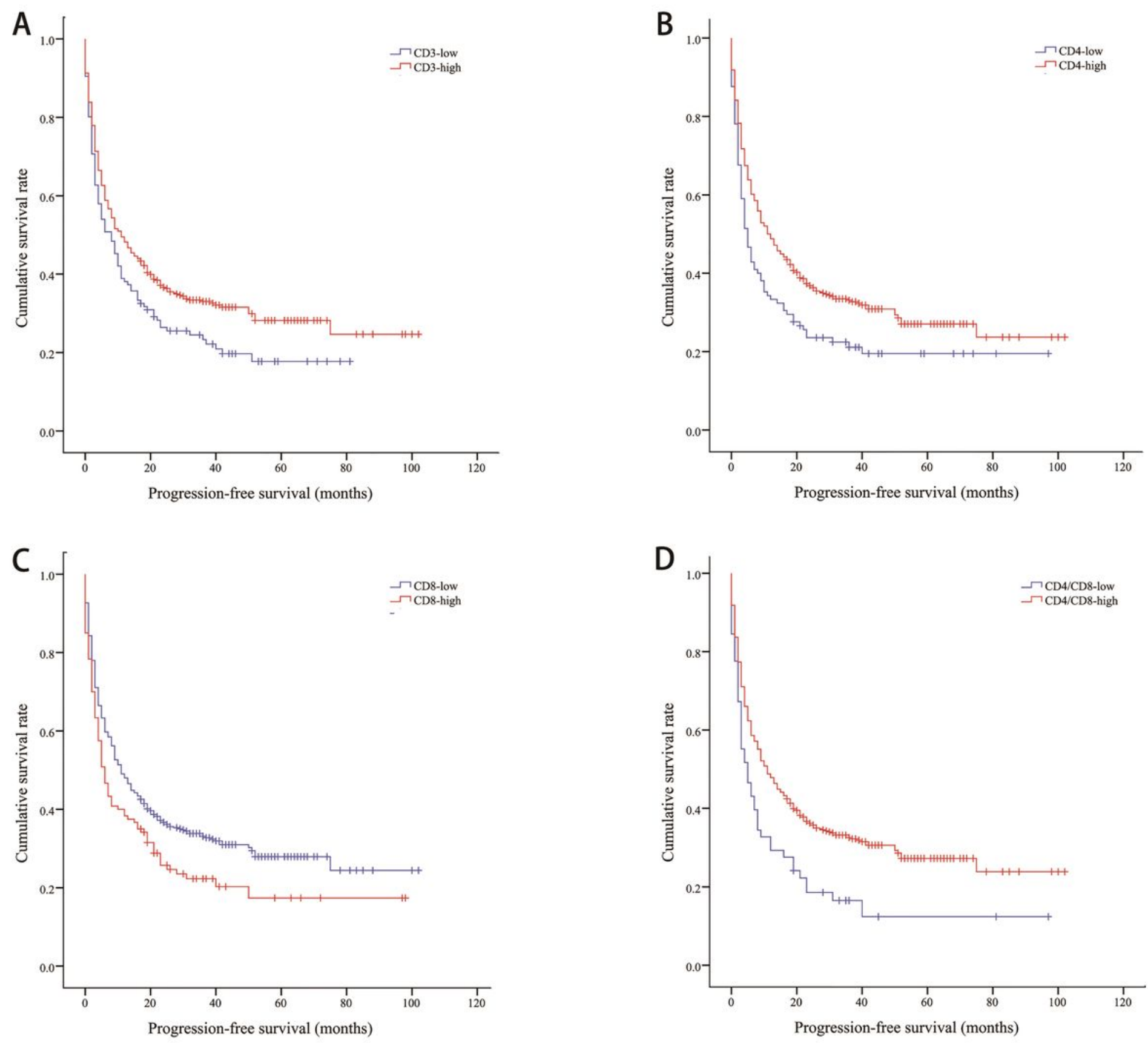

Figure 2

Kaplan-Meier curves showing progression-free survival by CD3 (A), CD4 (B), CD8 (C), CD4/CD8 (D) 


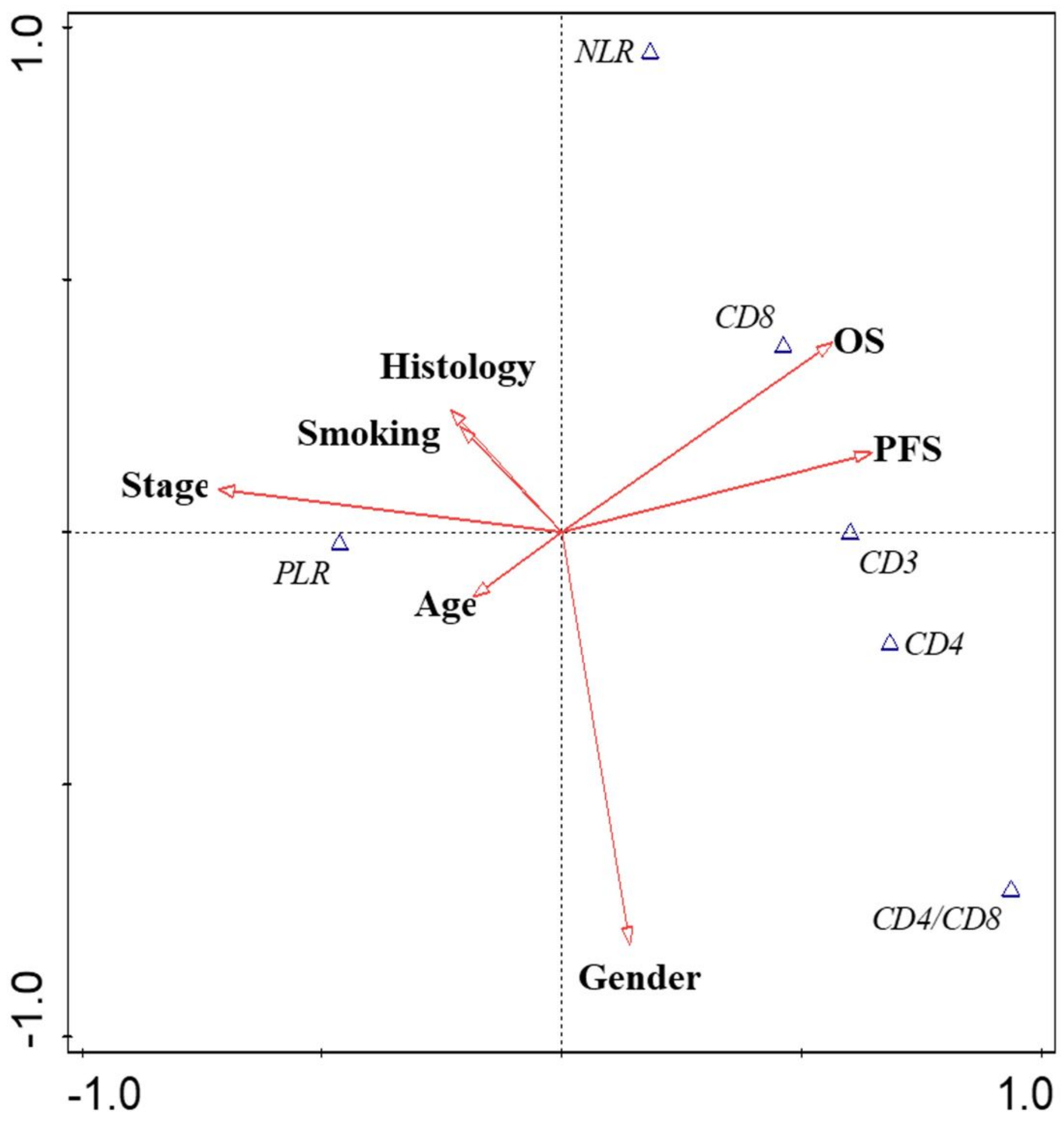

Figure 3

Canonical Correlation Analysis 


\section{Patients diagnosed with lung cancer and without previous treatment}

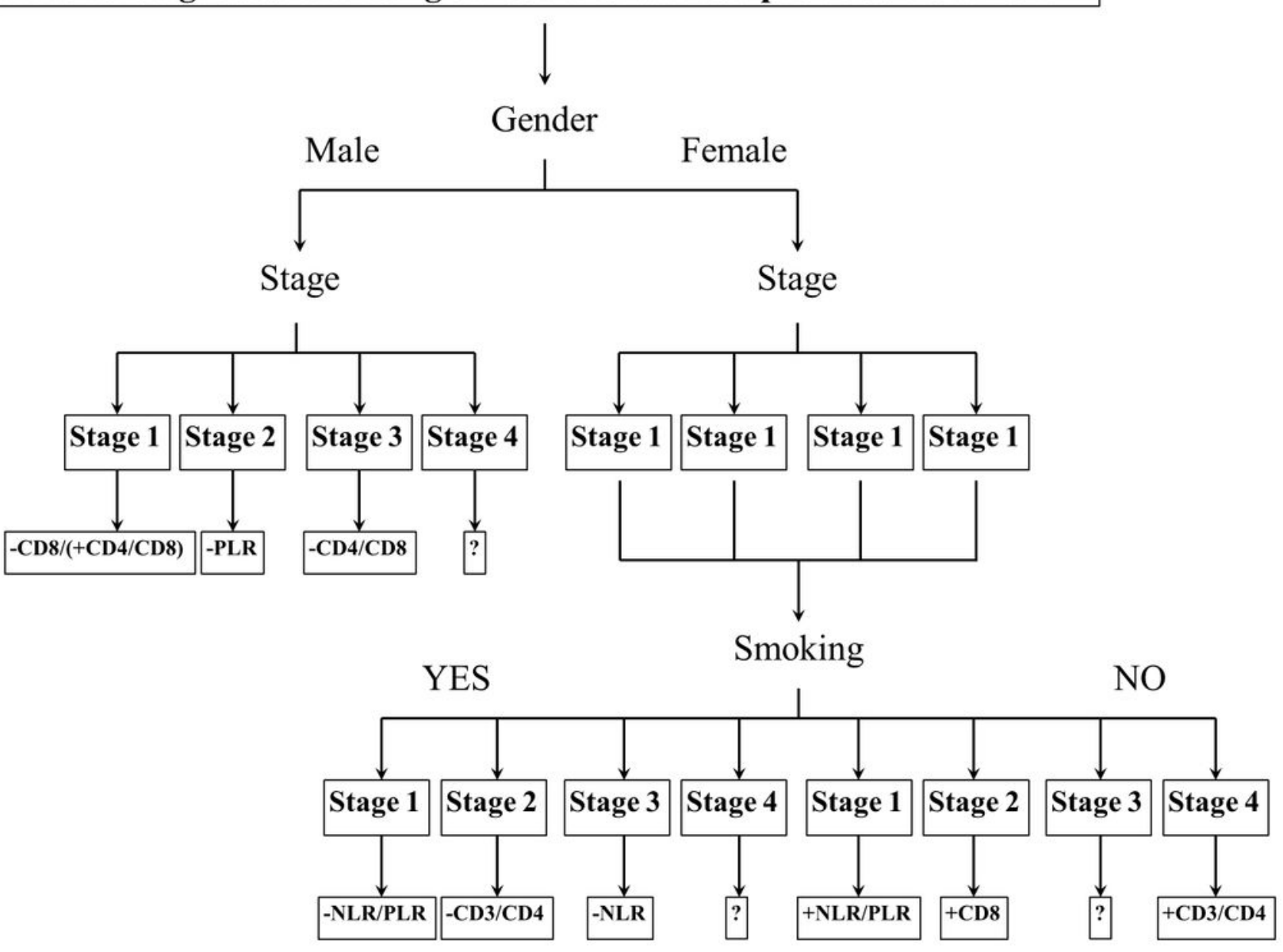

Figure 4

The biomarkers to assess the prognosis +: positive correlation; -: negative correlation; ?: no appropriate biomarkers in this work

\section{Supplementary Files}

This is a list of supplementary files associated with this preprint. Click to download.

- Additionalfilefiguretitlesandlegends.doc

- Additionalfile4.tif

- Additionalfile3.tif

- Additionalfile2.tif

- Additionalfile1.tif 